Article

\title{
Hemocyanins from Helix and Rapana Snails Exhibit in Vitro Antitumor Effects in Human Colorectal Adenocarcinoma
}

\author{
Ani Georgieva ${ }^{1, * \mathbb{D}}$, Katerina Todorova ${ }^{1}{ }^{\mathbb{D}}$, Ivan Iliev ${ }^{1}$, Valeriya Dilcheva ${ }^{1}$, Ivelin Vladov ${ }^{1}$, \\ Svetlozara Petkova ${ }^{1}$, Reneta Toshkova ${ }^{1}$, Lyudmila Velkova ${ }^{2}$, Aleksandar Dolashki ${ }^{2}$ and \\ Pavlina Dolashka ${ }^{2, *}$ \\ 1 Institute of Experimental Morphology, Pathology and Anthropology with Museum, Bulgarian Academy of \\ Sciences, Sofia 1113, Bulgaria; pda54@abv.bg (K.T.); taparsky@abv.bg (I.I.); val_dilcheva@yahoo.com (V.D.); \\ iepparazit@yahoo.com (I.V.); svetlozarapetkova@abv.bg (S.P.); reneta.toshkova@gmail.com (R.T.) \\ 2 Institute of Organic Chemistry with Centre of Phytochemistry, Bulgarian Academy of Sciences, Sofia 1113, \\ Bulgaria; lyudmila_velkova@abv.bg (L.V.); adolashki@yahoo.com (A.D.) \\ * Correspondence: georgieva_any@abv.bg (A.G.); dolashka@orgchm.bas.bg (P.D.); \\ Tel.: +359-029-792-384 (A.G.); +359 887-193-423 (P.D.)
}

Received: 10 June 2020; Accepted: 2 July 2020; Published: 5 July 2020

\begin{abstract}
Hemocyanins are oxygen-transporting glycoproteins in the hemolymph of arthropods and mollusks that attract scientific interest with their diverse biological activities and potential applications in pharmacy and medicine. The aim of the present study was to assess the in vitro antitumor activity of hemocyanins isolated from marine snail Rapana venosa $(\mathrm{RvH})$ and garden snails Helix lucorum $(\mathrm{HlH})$ and Helix aspersa $(\mathrm{HaH})$, as well the mucus of H. aspersa snails, in the HT-29 human colorectal carcinoma cell line. The effects of the hemocyanins on the cell viability and proliferation were analyzed by 3-(4,5-dimethylthiazol-2-yl)-2,5-diphenyltetrazolium bromide (MTT) assay and the alterations in the tumor cell morphology were examined by fluorescent and transmission electron microscopy. The results of the MTT assay showed that the mucus and $\alpha$-subunit of hemocyanin from the snail $H$. aspersa had the most significant antiproliferative activity of the tested samples. Cytomorphological analysis revealed that the observed antitumor effects were associated with induction of apoptosis in the tumor cells. The presented data indicate that hemocyanins and mucus from $H$. aspersa have an antineoplastic activity and potential for development of novel therapeutics for treatment of colorectal carcinoma.
\end{abstract}

Keywords: hemocyanin; snail Rapana venosa; snail Helix lucorum; snail Helix aspersa; antitumor activity; colorectal adenocarcinoma; apoptosis

\section{Introduction}

Neoplastic diseases are characterized as having high incidence and mortality and have significant health and social impacts. Conventional anticancer treatment includes a combination of surgery, radiation therapy, and chemotherapy [1]. However, traditional therapy has several drawbacks such as multidrug resistance, low selectivity, and toxicity to healthy tissues associated with severe side effects. Finding of selective and more efficient new drugs is one of the greatest challenges for pharmacology and medicine. Today, an extensive research effort has been focused on screening of compounds of natural origin with higher specificity and less adverse side effects [2]. In this context, bioactive compounds isolated from mollusk species attract a significant interest as good drug candidates for cancer therapeutic applications [3]. 
Numerous studies have indicated that hemocyanins, oxygen-carrying hemolymph metalloproteins, have a significant immunostimulatory and anticancer activity [4-7]. Molluscan hemocyanins are glycoproteins with high molecular masses and complex quaternary and oligosaccharide structures. They are usually composed of several structural subunits with approximate masses of 350-450 kDa, each consisting of seven or eight globular functional units connected by linker peptide strands, forming hollow cylinders [8]. The primary amino acid sequences of molluscan hemocyanins are highly divergent from mammalian sequences, which results in strong activation of the immune system. In addition, the carbohydrate moieties present in molluscan hemocyanins are considered responsible for their high immunogenicity. The carbohydrate structures of hemocyanins have been extensively studied in order to understand their organization, antigenicity, and biomedical properties $[9,10]$. The carbohydrate component of hemocyanins have been reported to be up to $9 \%(w / w)$ and contain diverse sugar moieties, including mannose, D-galactose, fucose, $\mathrm{N}$-acetyl-D-galactosamine, and $\mathrm{N}$-acetyl-glucosamine residues, as well as xylose, which is not usually present in animal proteins [11]. Hemocyanins are characterized with the presence of numerous $\mathrm{N}$-glycosylation sites and limited number of O-glycosylation sites [12]. Due to these structural properties, hemocyanins stimulate the mammalian immune system nonspecifically by interacting with macrophages, polymorphonuclears, $\mathrm{CD} 4+$, and CD8+ cells and induce potent humoral and cellular immune response [11,13]. Moreover, significant direct antitumor effects of hemocyanins have been established in various in vitro and in vivo tumor models [4,14-16].

The present study aimed to assess the in vitro antitumor activity of hemocyanins isolated from Helix aspersa, Helix lucorum, and Rapana venosa against colorectal carcinoma cell line HT-29 and to investigate morphological and ultrastructural alterations in the tumor cells.

\section{Materials and Methods}

\subsection{Materials}

Membranes were purchased from Millipore Ultrafiltration Membrane Filters, regenerated cellulose. 3-(4,5-Dimethylthiazol-2-yl)-2,5-diphenyltetrazolium bromide (MTT), ethidium bromide (EB), and acridine orange (AO) were purchased from Sigma-Aldrich, Schnelldorf, Germany. All culture reagents, Dulbecco's modified Eagle's medium (DMEM; Sigma-Aldrich, Schnelldorf, Germany), fetal bovine serum (FBS; Gibso/BRL, Grand Island, NY), L-glutamine, penicillin, and streptomycin (LONZA, Cologne, Germany) were used as received. The disposable consumables were supplied by Orange Scientific, Braine-l' Alleud, Belgium. HT-29 cell line-human colorectal adenocarcinoma was obtained from American Type Cultures Collection (ATCC, Rockville, MD, USA).

\subsection{Isolation of the Hemocyanin and Isoforms from Snail Rapana Venosa}

The hemolymph was collected from $R$. venosa marine snails living in the Black Sea after cutting the foot muscles, and it was filtrated and centrifuged at $10,000 \mathrm{rpm}$ and $4{ }^{\circ} \mathrm{C}$ for $20 \mathrm{~min}$ to remove rough particles and haemocytesas [17]. The crude hemolymph extract was ultrafiltrated (using membrane $100 \mathrm{kDa}$ Millipore Ultrafiltration Membrane Filters) and the fraction above $100 \mathrm{kDa}$ containing predominantly native $\mathrm{RvH}$ was ultracentrifugatied at 22,000 rpm and $4{ }^{\circ} \mathrm{C}$ for $180 \mathrm{~min}$ with rotor Kontron-Hermle A8.24 (centrifuge CENTRIKON). The sediment containing the native RvH was solubilized at a concentration of about $10 \%$ in $50 \mathrm{mM}$ Tris buffer (pH 7.5) and was purified by gel filtration on column Sephadex G-200. Dissociation of native RvH was achieved by dialyzing the protein against $0.13 \mathrm{M}$ glycine/ $\mathrm{NaOH}$ buffer, $\mathrm{pH}$ 9.6. The structural subunits $\mathrm{RvH} 1$ and $\mathrm{RvH} 2$ were separated on an ion-exchange chromatography by a 16/10 Q Sepharose High Performance column equilibrated with $50 \mathrm{mM}$ Tris/HCl buffer and $10 \mathrm{mM}$ EDTA (pH 8.5) with a linear gradient of $0.0-0.5 \mathrm{M}$ $\mathrm{NaCl}$ by FPLC system. 


\subsection{Isolation of the Native Hemocyanin and Isoforms from Snail H. Lucorum}

The hemolymph was collected from the foot of garden snail H. lucorum and rough particles and hemocytes were removed after filtration and centrifuged at $10,000 \mathrm{rpm}$ and $4{ }^{\circ} \mathrm{C}$ for $20 \mathrm{~min}$ [18]. After ultrafiltration of supernatant by membrane of $100 \mathrm{kDa}$ (Millipore Ultrafiltration Membrane Filters, Regenerated cellulose), we applied the fraction with molecular mass above $100 \mathrm{kDa}$, containing mostly hemocyanin, to ultracentrifugation at 22,000 rpm and $4{ }^{\circ} \mathrm{C}$ for $180 \mathrm{~min}$ with rotor Kontron-Hermle A8.24 (centrifuge CENTRIKON). The sediment with total hemocyanin was solubilized in concentration of about $5 \%$ in $0.1 \mathrm{M}$ sodium acetate buffer, $\mathrm{pH} 5.7$.

The isoform $\beta \mathrm{c}-\mathrm{HlH}$ was isolated after precipitation of native $\mathrm{HlH}$ during $4-5$ days dialysis against $10 \mathrm{mM}$ sodium acetate buffer $\left(\mathrm{pH} \mathrm{5.1)}\right.$ at $4{ }^{\circ} \mathrm{C}$ and the buffer was renewed every $12 \mathrm{~h}$. The $\beta \mathrm{c}-\mathrm{HlH}$ was sedimented by centrifugation at $15,000 \times g$, at $4{ }^{\circ} \mathrm{C}$ for $30 \mathrm{~min}$. The precipitate was dissolved in $100 \mathrm{mM}$ sodium phosphate buffer ( $\mathrm{pH}$ 6.5) and further purified by anion exchange chromatography on a 16/10 Q Sepharose High Performance column using a linear NaCl gradient (0.0-0.5 M) in $50 \mathrm{mM}$ Tris- $\mathrm{HCl}$ buffer, $\mathrm{pH} 7.8$.

Both subunits, $\alpha_{D}-\mathrm{HlH}$ and $\alpha_{N}-\mathrm{HlH}$, dissolved in the supernatant, were purified by gel filtration chromatography on a Sephacryl S 300 column, were equilibrated and eluted with $50 \mathrm{mM}$ Tris buffer ( $\mathrm{pH}$ 7.5), and further concentrated by ultrafiltration (100 kDa, Millipore Ultrafiltration Membrane Filters, regenerated cellulose).

\subsection{Isolation of the Native Hemocyanin and Mucus from Snail H. Aspersa}

The native $\mathrm{HaH}$ was isolated after concenrtation of the hemolymph collected from the foot of garden snail $H$. aspersa by ultrafiltration (using $100 \mathrm{kDa}$, Amicon PM membranes) [4]. After ultracentrifugation at 22,000 rpm (rotor Kontron-Hermle A8.24, centrifuge CENTRIKON) and $4{ }^{\circ} \mathrm{C}$ for $3 \mathrm{~h}$, the native $\mathrm{HaH}$ was sedimented. After removal of the supernatant, the precipitated $\mathrm{HaH}$ was solubilized in $50 \mathrm{mM}$ Tris buffer ( $\mathrm{pH} 7.5$ ) containing $20 \mathrm{mM} \mathrm{CaCl}_{2}$ and $10 \mathrm{mM} \mathrm{MgCl}_{2}$ and further purified by gel filtration chromatography on a Sepharose $6 \mathrm{~B}$ column $(90 \times 2.4 \mathrm{~cm})$.

\subsection{Separation of H. Aspersa Hemocyanin Isoforms}

Three isoforms $\left(\alpha_{\mathrm{D}}-\mathrm{HaH}, \alpha_{\mathrm{N}}-\mathrm{HaH}\right.$, and $\left.\beta \mathrm{c}-\mathrm{HaH}\right)$ were separated after 4 days of dialysis against $10 \mathrm{mM}$ sodium acetate buffer $(\mathrm{pH} 5.3)$ at $4{ }^{\circ} \mathrm{C}$, renewed every $12 \mathrm{~h}$. The isoform $\beta \mathrm{c}-\mathrm{HaH}$ precipitated after centrifugation and solubilized in $0.1 \mathrm{M}$ sodium phosphate buffer ( $\mathrm{pH}$ 6.5), and was further purified by gel filtration chromatography on a Sepharose 6B column and eluted with buffer of $50 \mathrm{mM}$ Tris- $\mathrm{HCl}$, pH 7.5. Two $\alpha$-isoforms $\left(\alpha_{\mathrm{D}+\mathrm{N}}\right)$ in supernatant were concentrated by ultrafiltration (Millipore Ultrafiltration Membrane Filters, regenerated cellulose) and purified of FPLC-system by a 16/10 Q Sepharose High Performance column using a linear $\mathrm{NaCl}$ gradient $(0.0-1.0 \mathrm{M})$ in $50 \mathrm{mM}$ Tris- $\mathrm{HCl}$ buffer, $\mathrm{pH} 8.2$.

The mucus was collected from the foot of $H$. aspersa snails that were grown in Bulgarian eco-farms. After several steps of purification and homogenization, including filtration and centrifugation for removal of rough particles, the crude mucus extract was obtained [19].

Mucus extract from $H$. aspersa was analyzed by sodium dodecyl sulphate polyacrylamide gel electrophoresis (SDS-PAGE) with the molecular weight marker ranging from $250 \mathrm{kDa}$ to $10 \mathrm{kDa}$ using a 5\% stacking gel and 12\% resolving gel, according to Laemmli method with modifications [20]. All tested hemocyanins and their isoforms were analyzed by $8 \%$ polyacrylamide gel electrophoresis under native conditions, as described [21].

\subsection{Cell culture and Cell Viability}

HT-29 and Balb/c 3T3 cells were cultured in $75 \mathrm{~cm}^{2}$ tissue culture flasks in Dulbecco's modified Eagle's medium supplemented with $10 \%$ fetal calf serum, $2 \mathrm{mM}$ glutamine, and the antibiotics penicillin $\left(100 \mathrm{U} \mathrm{mL}^{-1}\right)$ and streptomycin $\left(100 \mu \mathrm{g} \mathrm{mL}^{-1}\right)$ at $37^{\circ} \mathrm{C}$ and $5 \% \mathrm{CO}_{2}$ and $90 \%$ relative humidity. 
Cell viability was assessed by MTT (methyl thiazol tetrazolium bromide) assay, as described previously [22]. Briefly, cells were plated in a 96-well microtiter plate at a density of $1 \times 10^{4}$ cells per well in a final volume of $100 \mu \mathrm{L}$ DMEM medium. HT-29 cells were treated with six different concentrations of the hemocyanin samples $(31.25-1000 \mu \mathrm{g} / \mathrm{mL})$ for $72 \mathrm{~h}$. Parallel experiments with the same treatment and incubation regimen were performed on Balb/c 3T3 cells to assess the cytotoxic activity of the tested samples in non-tumor cells. After treatment, the cells were incubated with MTT dye at a concentration of $50 \mu \mathrm{g} / 100 \mu \mathrm{L}$ for $3 \mathrm{~h}$ at $37^{\circ} \mathrm{C}$. The cells were thereafter lysed with $\mathrm{DMSO} / 96 \%$ ethanol $(1: 1 v / v)$ solution. Absorbance of the reduced intracellular formazon product was read at $570 \mathrm{~nm}$ in a microtiter plate reader (TECAN, Sunrise, Groedig/Salzburg, Austria).

\subsection{Fluorescent Microscopy}

The morphological alterations in HT-29 cells induced by the test samples that showed higher cytotoxic activity were analyzed by fluorescent microscopy. HT-29 cells were cultured on $13 \mathrm{~mm}$ diameter cover glasses in 24-well plates and were treated for $24 \mathrm{~h}$ with hemocyanins in concentrations approximating the $\mathrm{IC}_{50}$ value established by the MTT test and concentrations lower and higher than the $\mathrm{IC}_{50}$ value. Cells treated with the standard anticancer drug doxorubicin were used as a positive control for the experiments. Doxorubicine was applied at concentrations equal to the $\mathrm{IC}_{50}$ value $(2.7 \mu \mathrm{g} / \mathrm{mL})$ established in our previous studies. The control and treated cells were stained by two different methods.

\subsubsection{Acridine Orange/Ethidium Bromide Double Staining}

Acridine orange ( $\mathrm{AO}$ ) and ethidium bromide (EB) (live/dead) staining was performed as previously described [23]. Briefly, cell preparations of HT-29 cells were stained with the fluorescent dyes AO $(5 \mu \mathrm{g} / \mathrm{mL})$ and EB $(5 \mu \mathrm{g} / \mathrm{mL})$ in phosphate-buffered saline (PBS) and mounted on microscope slides.

\subsubsection{DAPI Staining}

The alterations in the nuclear morphology of the tumor cells induced by hemocyanins were studied after staining with DNA binding dye 4',6-diamidine-2'-phenylindole dihydrochloride (DAPI). The cells were fixed with methanol, incubated for $15 \mathrm{~min}$ in $1 \mu \mathrm{g} / \mathrm{mL}$ DAPI in methanol in the dark, and mounted with glycerol on microscope slides.

Stained cells were visualized and examined under a fluorescence microscope (Leica DM 5000B, Wetzlar, Germany).

\subsection{Transmission Electron Microscopy (TEM)}

Ultrastructural studies of cells exposed to bioactive compounds isolated from Helix aspersa at cytotoxic doses (concentrations equal or close to their $\mathrm{IC}_{50}$ values) were processed according to routine techniques for this type of assay. They were fixed for $1 \mathrm{~h}$ with $2.5 \%$ glutaraldehyde in $0.1 \mathrm{M} \mathrm{pH} 7.3$ phosphate buffer, postfixed for $2 \mathrm{~h}$ in $1 \% \mathrm{OsO}_{4}$, dehydrated, and included in Durcupan ACM Fluka. Ultra-thin sections were prepared on Reichert Ultramicrotome and stained with $2 \%$ uranyl acetate and $2 \%$ lead citrate. For the TEM study, we used an Opton transmission electron microscope.

\subsection{Statistical Analysis}

Statistical analysis was performed by one-way ANOVA followed by Bonferroni's post hoc test (GraphPad Prism software package). $p<0.05$ was accepted as the lowest level of statistical significance. Nonlinear regression (curve fit) analysis (GraphPad Prism) was applied to determine the concentrations inducing $50 \%$ inhibition of the cell growth ( $\mathrm{IC}_{50}$ values). 


\section{Results}

\subsection{Isolation of Bioactive Compounds from the Three Mollusk Species}

Total hemocyanins from garden snails Helix aspersa and Helix lucorum (HaH-total; HlH-total), their isoforms (subunits $\beta \mathrm{c}-\mathrm{HaH}, \alpha-\mathrm{HaH}, \beta \mathrm{c}-\mathrm{HlH}$, and $\alpha-\mathrm{HlH}$ ), Helix aspersa mucus, and subunits of Rapana venosa hemocyanin ( $\mathrm{RvH}$ I and $\mathrm{RvH}$ II) were isolated and purified as previously described [4,17,18]. Hemocyanins are freely dissolved in the hemolymph of species in Mollusca and Arthropoda as a major protein constituent (90-98\%) of this fluid. Specific absorption coefficient $\mathrm{A}_{278} \mathrm{~nm}=1.413 \mathrm{~mL} \cdot \mathrm{mg}^{-1} \cdot \mathrm{cm}^{-1}$ for HaH was used for determination of the protein concentration [24].

The hemolymph was collected from $R$. venosa marine snails living in the Black Sea and garden snails $H$. aspersa and H. lucorum after cutting the foot muscles [17-19]. The hemocyanins with molecular mass $\approx 8 \mathrm{MDa}$ were isolated from the crude hemolymph extract after ultrafiltration using membrane $100 \mathrm{kDa}$. Native RvH was obtained after ultracentrifugation at 22,000 rpm and $4{ }^{\circ} \mathrm{C}$ for $180 \mathrm{~min}$ and purified by gel filtration on column Sephadex G-200. After dissociation of native RvH by dialyzing the protein against $0.13 \mathrm{M}$ glycine/ $\mathrm{NaOH}$ buffer ( $\mathrm{pH}$ 9.6) two structural subunits $\mathrm{RvH} 1$ and $\mathrm{RvH} 2$ were separated on an ion-exchange chromatography by a 16/10 Q Sepharose High Performance column equilibrated with $50 \mathrm{mM}$ Tris/ $\mathrm{HCl}$ buffer and $10 \mathrm{mM}$ EDTA (pH 8.5) with a linear gradient of $0.0-0.5 \mathrm{M}$ $\mathrm{NaCl}$ by FPLC system [17].

The native H. lucorum [18] and H. aspersa [4] hemocyanins are organized by three structural subunits $\left(\beta \mathrm{c}-\mathrm{HaH}, \alpha_{\mathrm{D}}-\mathrm{HaH}\right.$, and $\left.\alpha_{\mathrm{N}}-\mathrm{HaH}\right)$ with molecular weight $(\mathrm{MW}) \approx 450 \mathrm{kDa}$. The $\beta \mathrm{c}$-isoforms were precipitated from the hemolymph and further purified by gel filtration chromatography on a Sepharose 6B column, and eluted with buffer $50 \mathrm{mM}$ Tris- $\mathrm{HCl}, \mathrm{pH} 7.5$. After removal of $\beta \mathrm{c}$-isoform, both $\alpha$-isoforms in supernatant were purified of FPLC-system by gel filtration chromatography on a Sephacryl S 300 column, equilibrated and eluted with $50 \mathrm{mM}$ Tris buffer, pH 7.5

The mucus collected from the foot of $H$. aspersa snails was purified after filtration and centrifugation of the crude mucus extract [19].

The tested hemocyanins were analyzed by $8 \%$ native PAGE (Figure 1) [21] to confirm their molecular masses and purity. As shown in Figure 1a, purity of total hemocyanin hemocyanins (line 2 of $H$. aspersa, line 5 of $R$. venosa, and line 8 of $H$. lucorum) and their structural subunits (lines 3, 4, 6, 7, and 10) is about $90 \%$. Line 9 shows two main bands that correspond to the two isoforms $\alpha \mathrm{N}-\mathrm{HlH}$ and $\alpha \mathrm{D}-\mathrm{HlH}$.

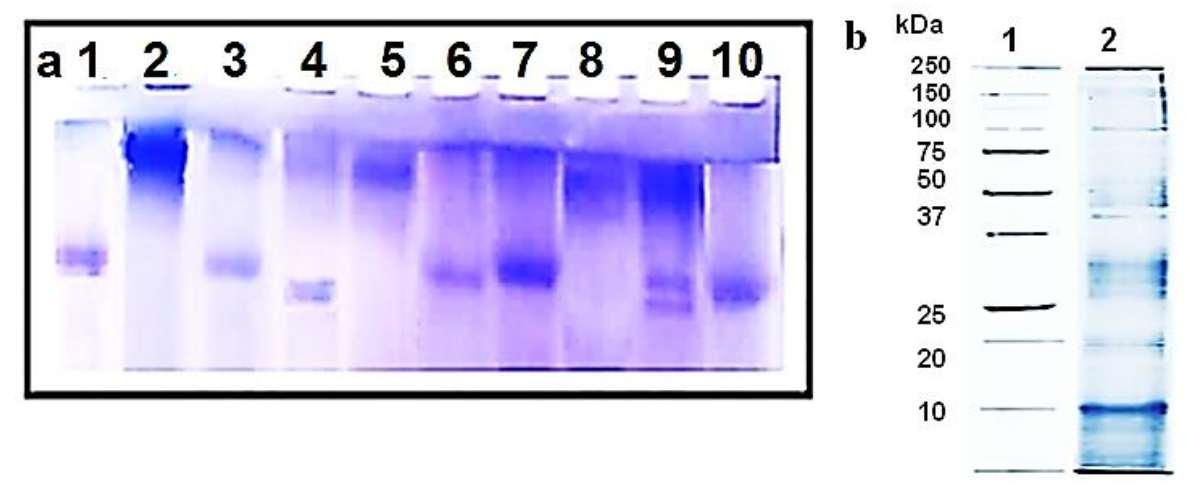

Figure 1. (a) The $8 \%$ native gel electrophoresis of the tested hemocyanins with Coomassie Blue G-250 dye: positions (1) standard ferritin (450 kDa); (2) total Helix aspersa hemocyanin; (3) two $\alpha$-isoforms of $H$. aspersa hemocyanin; (4) structural subunit $\beta \mathrm{c}-\mathrm{HaH}$; (5) total Rapana venosa hemocyanin; (6) structural subunit RvH I; (7) structural subunit RvH II; (8) total Helix lucorum hemocyanin; (9) two $\alpha$-isoforms of $H$. lucorum hemocyanin; (10) structural subunit $\beta c-H l H$. (b) The $12.0 \%$ SDS-PAGE analysis visualized by staining with Coomassie Blue G-250: (1) molecular weights of standard proteins from Bio-rad; (2) mucus extract from $H$. aspersa. 
The $12 \%$ SDS-PAGE analysis of the mucus extract showed that the mucus is a complex mixture of various biological substances such as antimicrobial peptides and proteins (Figure 1b, line 2).

\subsection{Effects of the Isolated Bioactive Compounds on the Viability and Proliferative Activity of HT-29 Tumor Cells}

The effects of the hemocyanin samples on the viability and proliferative activity of the colorectal adenocarcinoma cells were assessed by MTT assay after $72 \mathrm{~h}$ of treatment (Figure 2).

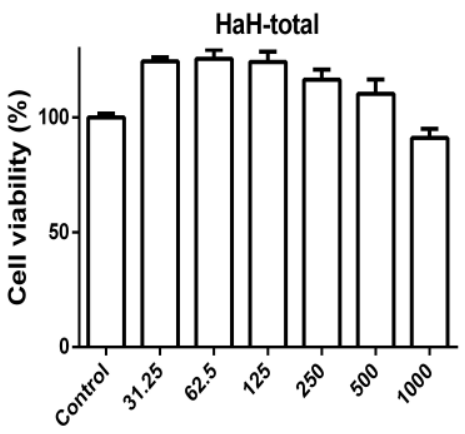

Concentration $(\mu \mathrm{g} / \mathrm{mL})$
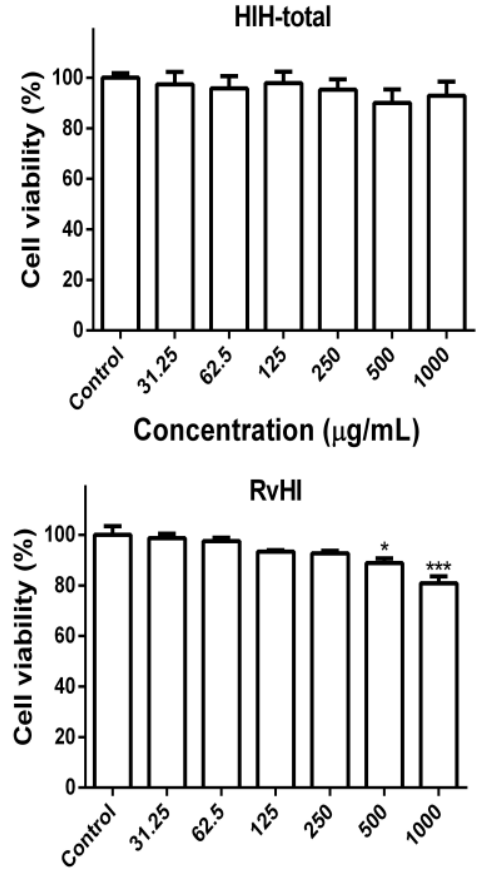

Concentration $(\mu \mathrm{g} / \mathrm{mL})$

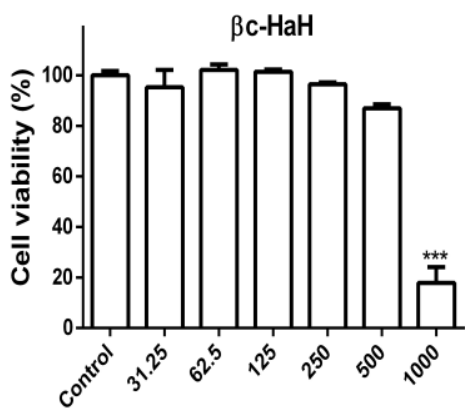

Concentration $(\mu \mathrm{g} / \mathrm{mL})$
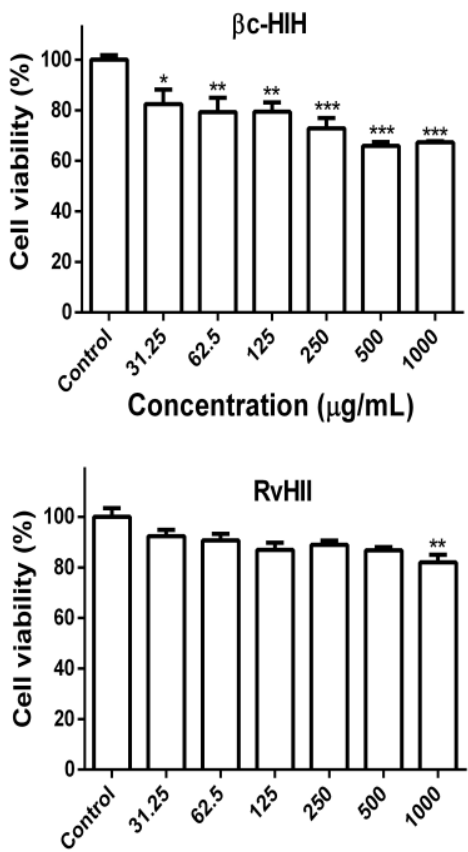

Concentration $(\mu \mathrm{g} / \mathrm{mL})$

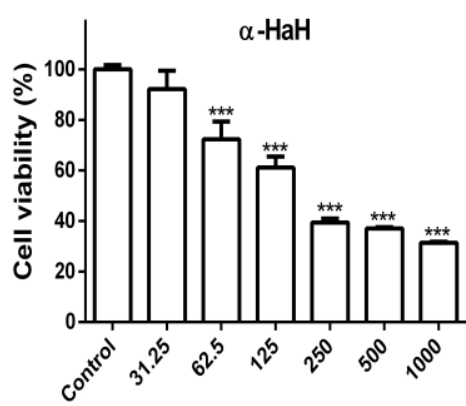

Concentration $(\mu \mathrm{g} / \mathrm{mL})$
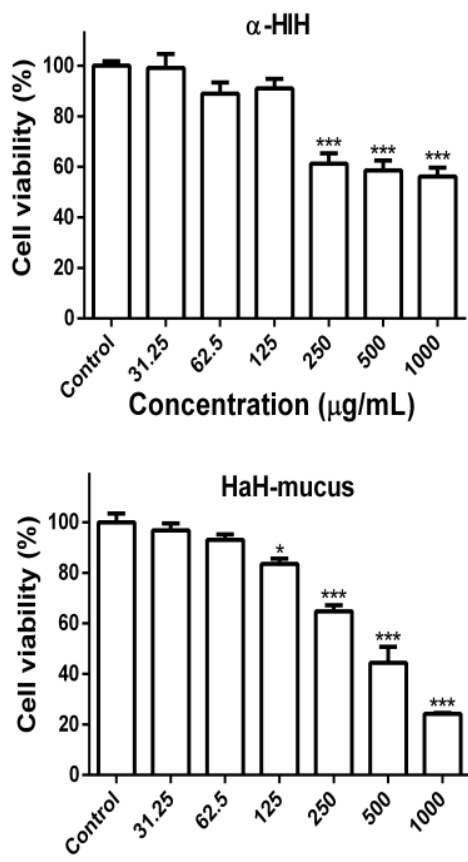

Concentration $(\mu \mathrm{g} / \mathrm{mL})$

Figure 2. Antiproliferative effect of hemocyanins from $H$. aspersa (HaH-total) and its structural subunits $\beta \mathrm{c}-\mathrm{HaH}$ and $\alpha-\mathrm{HaH}$; hemocyanin from H. lucorum $(\mathrm{HlH}$-total) and its subunits $\beta \mathrm{c}-\mathrm{HlH}$ and $\alpha-\mathrm{HlH}$; subunits RvH I and RvH II of hemocyanin from $R$. venosa $(\mathrm{RvH})$; mucus extract of Helix aspersa on HT-29 colorectal carcinoma cell line. ${ }^{*} p<0.05 ;{ }^{* *} p<0.01 ;{ }^{* * *} p<0.001$

The results of the MTT assay showed that the total hemocyanins of H. aspersa and H. lucorum did not significantly affect the viability of the colon carcinoma cells. However, the isolated structural subunits $\alpha-\mathrm{HaH}, \beta \mathrm{c}-\mathrm{HlH}$, and $\alpha-\mathrm{HlH}$ of hemocyanins as well the mucus from snail $H$. aspersa induced significant $(p<0.001$ as compared to the untreated control) and dose-dependent reduction of the cell viability and proliferation.

The $\beta \mathrm{c}-\mathrm{HaH}$ subunit induced the highest inhibition of cell viability at a concentration of $1000 \mu \mathrm{g} / \mathrm{mL}$ compared to the other tested subunits. Both subunits, RvH I and RvH II, of R. venosa hemocyanin significantly reduced $(p<0.001)$ the cell viability only at higher concentrations (500 and $1000 \mu \mathrm{g} / \mathrm{mL}$, 
respectively). Of all tested samples, the subunits $\alpha-\mathrm{HaH}$ and the mucus of snail $H$. aspersa showed the highest in vitro antitumor activity against HT-29 colon carcinoma cells. On the basis of the results of the MTT assay, we calculated the half-maximal inhibitory concentrations $\left(\mathrm{IC}_{50}\right)$ and compared them to the $\mathrm{IC}_{50}$ determined by MTT assay on Balb/c3T3 cells (Table 1).

Table 1. The half-maximal inhibitory concentrations $\left(\mathrm{IC}_{50}\right)$ of hemocyanins and their subunits isolated from $H$. aspersa, H. lucorum, and R. venosa determined by MTT assay on HT-29 and Balb/c3T3 cells.

\begin{tabular}{ccc}
\hline IC $_{\mathbf{5 0}}$ Values $(\boldsymbol{\mu g} / \mathbf{m L})$ & HT-29 & Balb/c 3T3 \\
\hline HaH-total & $>1000$ & 934.1 \\
Subunit $\beta \mathrm{c}-\mathrm{HaH}$ & 733.8 & $>1000$ \\
Subunits $\alpha-\mathrm{HaH}$ & 235.3 & 514.6 \\
HlH-total & $>1000$ & $>1000$ \\
Subunit $\beta \mathrm{c}-\mathrm{HlH}$ & $>1000$ & $>1000$ \\
Subunits $\alpha-\mathrm{HlH}$ & $>1000$ & $>1000$ \\
Subunit RvH I & $>1000$ & $>1000$ \\
Subunit RvH II & $>1000$ & $>1000$ \\
Ha-mucus & 415.7 & 825.1 \\
\hline
\end{tabular}

The results showed that HT-29 cells were more sensitive to the aniproliferative and cytotoxic effects of the tested samples than Balb/c3T3 cells.

\subsection{Apotogenic Effects of the Isolated Bioactive Compounds}

3.3.1. Vital Double Staining of HT-29 Tumor Cells with Acridine Orange/Ethidium Bromide Acridin

For assessment of the apoptogenic potential of the selected samples, we examined the morphological alterations in HT-29 tumor cells. For this purpose, tumor cells were treated with three different concentrations of subunit $\alpha-\mathrm{HaH}$ and H. aspersa. The changes in the cell morphology induced by the hemocyanins were examined under fluorescent microscope after staining with $\mathrm{AO} / \mathrm{EB}$ (Figure 3).

Control cells were uniformly stained green and showed normal morphology and monolayer growth characteristics of the tumor cell line (Figure 3a). The positive control substance doxorubicin induced clearly pronounced apoptotic changes in the tumor cells (Figure $3 b$ ). Distinct dose-dependent morphological changes were found in HT-29 cells treated with $\alpha-\mathrm{HaH}$ and the mucus of $H$. aspersa. The cell density of the monolayer was reduced and cells with intensive green fluorescence indicative of early apoptotic chromatin condensation changes were observed in treated cell cultures. In addition, late apoptotic cells with condensed chromatin, fragmented nuclei, and red-orange staining indicating the loss of membrane integrity and entry of ethidium bromide into the cell were also present. 

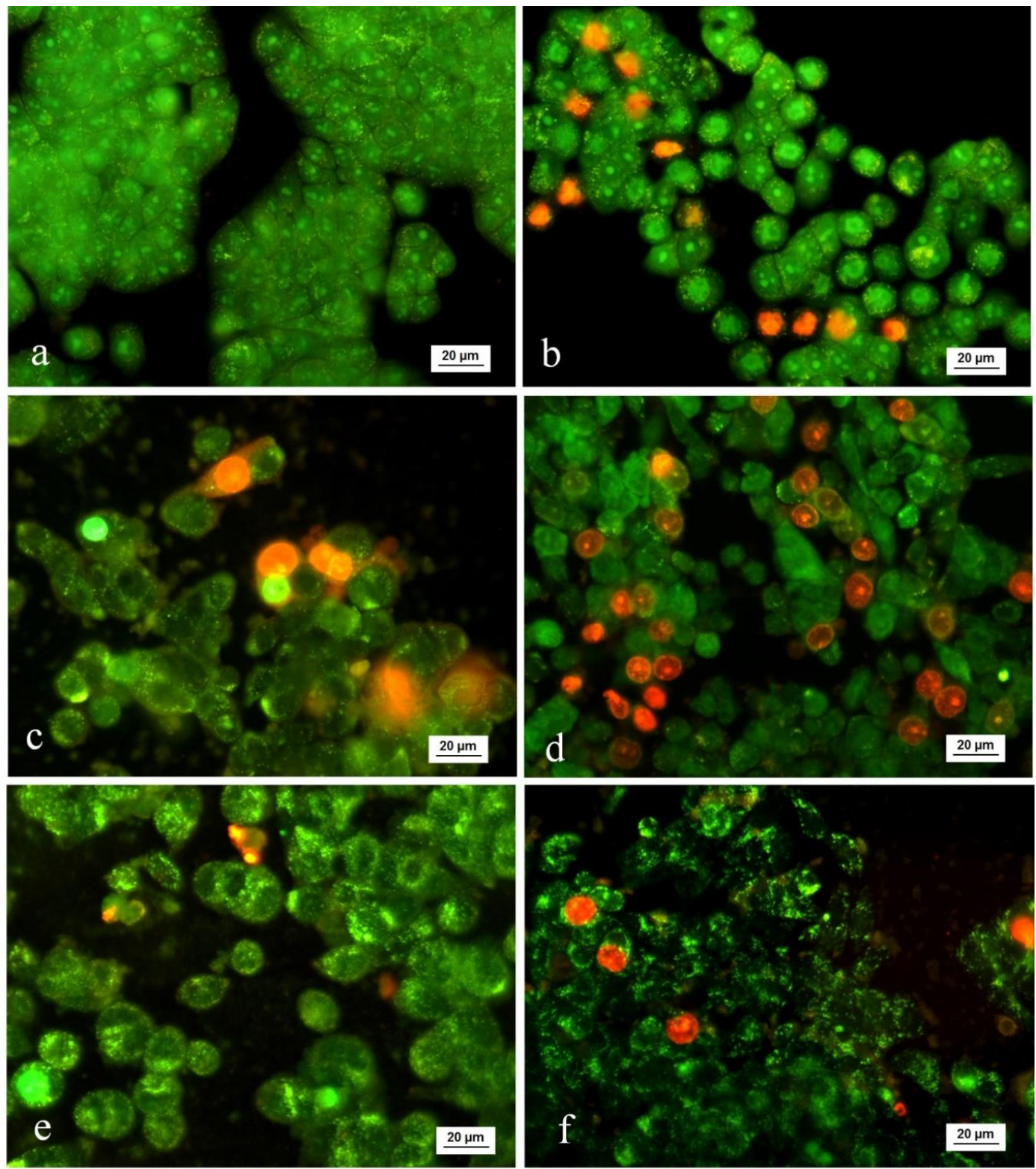

Figure 3. Fluorescence microscopic images of acridine orange (AO)/ethidium bromide (EB)-stained HT-29 colorectal carcinoma cells after treatment with bioactive compounds isolated from $H$. aspersa: (a) control; (b) doxorubicin $2.7 \mu \mathrm{g} / \mathrm{mL}$; (c) subunit $\alpha-\mathrm{HaH} 200 \mu \mathrm{g} / \mathrm{mL}$; (d) subunit $\alpha-\mathrm{HaH} 800 \mu \mathrm{g} / \mathrm{mL}$;

(e) H. aspersa mucus $400 \mu \mathrm{g} / \mathrm{mL}$; (f) H. aspersa mucus $800 \mu \mathrm{g} / \mathrm{mL}$.

\subsubsection{DAPI Staining of HT-29 Tumor Cells}

Further, the alterations in the nuclear morphology of the HT-29 cells induced by subunits $\alpha-\mathrm{HaH}$ and the mucus were studied by fluorescent microscopy after staining with DNA-binding dye DAPI (Figure 4).

The control HT-29 tumor cells showed typical morphology of the nucleus with homogenous blue staining, and cells in mitosis phase were observed. The nuclei of the cells treated with the $\alpha-\mathrm{HaH}$ subunits and the mucus were irregular in shape, more brightly colored, and had intense condensation of chromatin. Some treated cells showed nuclear fragmentation and formation of apoptotic bodies. Mitotic figures were not found in cells exposed to hemocyanin and mucus. 

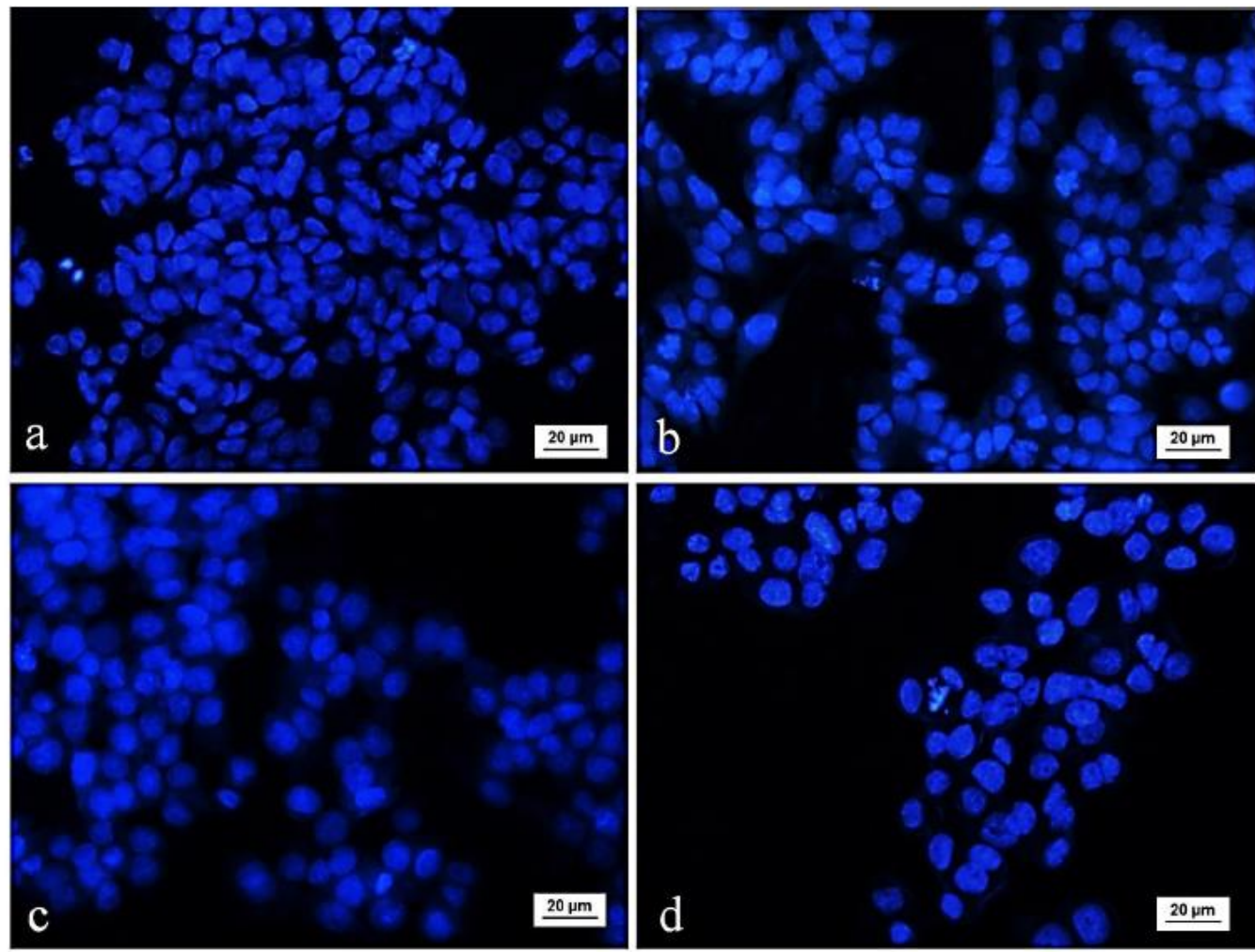

Figure 4. Fluorescence microscopic images of 4',6-diamidine-2'-phenylindole dihydrochloride (DAPI)-stained HT-29 colorectal carcinoma cells after treatement with bioactive compounds isolated from garden snail Helix aspersa: (a) control; (b) Helix aspersa mucus $400 \mu \mathrm{g} / \mathrm{mL}$; (c) subunit $\alpha$-HaH 100 $\mu \mathrm{g} / \mathrm{mL}$; (d) subunit $\alpha-\mathrm{HaH} 200 \mu \mathrm{g} / \mathrm{mL}$.

\subsection{Transmission Electron Microscopy}

The ultrastructural alterations induced by the subunits $\alpha-\mathrm{HaH}$ and the mucus from garden snail H. aspersa in HT-29 tumor cells were examined by transmission electron microscopy (Figure 5).

Our TEM observations of HT-29 cells in the control culture showed bipolar elongated cells with normal morphology (Figure 5a). The nucleus and the cytoplasm of the untreated cells had a normal structure, were relatively electronically dense, and were without cellular inclusions. The nucleus was more centrally located and several vesicles and the endoplasmic reticulum was peripherally observed. The cells' nuclei exhibited adenocarcinoma-specific appearance with prominent nucleoli. The notable superficial cellular membrane protrusions/microvilli evenly distributed on the surface of the plasmalemma are also typical for the carcinoma cells.

The ultrastructural aspects of the HT-29 cells treated with different test compounds showed mild to more pronounced changes (Figure $5 b$ ). The subunits $\alpha-\mathrm{HaH}$ and the mucus extract seriously affected cell morphology. The lesions were mainly expressed in loss of polarity and rounded shapes. Numerous cytoplasmic vesicles were observed, being dispersed throughout the cytoplasm along with single electron-dense objects of a larger number and size (likely disorganization of the cytoskeleton and vacuolization of the organelles along the apoptosis pathway). No nuclear fragmentation was found after subunits' $\alpha-\mathrm{HaH}$ exposure. The observed cells were also characterized by enlightened nuclei and cytoplasm, budding to form apoptotic bodies including parts of the cytoplasm.

The cells treated with the Helix aspersa mucus showed changes similar to the enlightened nuclei presented above, with separate small condensates of heterochromatin, focal perinuclear expansions of the membrane space of endoplasmic reticulum, and abundant organelle vacuolization (Figure 5c). The appearance of different electron-dense bodies and single autophagosomes or mitophagosome-like structures in cells were observed. Rare nuclear fragmentation, formation of apoptotic bodies with 
parts of the cytoplasm, and vacuoles within them were found as serious morphological alterations. In addition, extended nuclei were observed here, leading to changed nucleus-cytoplasm index.

\section{Discussion}

The search for novel, more effective, and safe antitumor medicines with natural origin is one of the main trends of contemporary oncology research. In this respect, hemocyanin oligomeric copper-containing glycoproteins that function as oxygen carriers in the hemolymph of mollusk and arthropod species represent significant interest because they combine strong immunostimulating activity and direct anticancer effects [5,6,25-27]. Among this class of compounds, the hemocyanin obtained from Megathura crenulata, known as keyhole limpet hemocyanin (KLH), has been most extensively studied and has found a number of biotechnological and medical applications. Clinical studies have shown that KLH treatment significantly reduces the tumor recurrence of patients with urinary bladder carcinoma [11]. It has also found an application as a bio-adjuvant and protein carrier in experimental antiviral and anticancer vaccines $[16,28,29]$. Moreover, KLH has been reported to induce significant reduction in the proliferation and viability of prostate cancer cells, estrogen-dependent breast and estrogen-independent breast cancer cells, and Barrett's esophageal adenocarcinoma cells $[14,30]$.

The diverse biological activities and increasing biomedical applications of KLH have led to growing interest and a search of other hemocyanins with similar or more potent immunostimulatory and antitumor properties. In the present study, the antitumor activity of total hemocyanins isolated from $H$. aspersa, $H$. lucorum, and their subunits; subunits of $R$. venosa hemocyanin; and $H$. aspersa mucus was examined in the HT-29 human colorectal carcinoma cell line. The results showed that the total hemocyanins did not significantly affect the viability of the colorectal carcinoma cells, while the isolated hemocyanin subunits induced a statistically significant decrease of the tumor cell growth. Similarly, in a previous study, it was found that the subunits of H. lucorum hemocyanin induce stronger inhibition of the tumor growth of bladder carcinoma CAL-29 cells as compared to the effect of native $\mathrm{HlH}$ [26]. It could be supposed that the potent tumor inhibiting activity is due to the specific oligosaccharide structures, which are more easily accessible in the isolated structural subunits. In addition to hemocyanin subunits, the H. aspersa mucus also showed a significant anticancer effect against HT-29 carcinoma cells. The bioactive compounds, structural subunits $\alpha-\mathrm{HaH}, \beta c-\mathrm{HaH}$, and mucus, isolated from garden snail $H$. aspersa, appeared to be the most active of all tested samples in inhibiting the colon cancer cell growth. This result is in agreement with the data reported by Matusiewicz et al., indicating that the application of extracts from lyophilized mucus and foot tissues of $H$. aspersa decrease the viability of the colon cancer cell line Caco-2 [31].

The reduction of the viability the HT-29 cells induced by treatment with $\mathrm{HlH}$ subunits was statistically significant with a clear dose dependency, but it was slightly weaker than those of $\mathrm{HaH}$ subunits. The subunits of $R$. venosa hemocyanin showed an antitumor effect only at the higher tested concentrations. Hemocyanins isolated from the land snail $H$. pomatia and marine snail $R$. thomasiana were previously found to express strong immunostimulatroy action and to inhibit tumor cell growth in a murine model of colon carcinoma [32]. These findings taken together with the results of the present study demonstrate that the hemocyanins isolated from different mollusk species have significant antitumor effects against colorectal carcinoma.

The tested bioactive substances, mucus and $\alpha-\mathrm{HaH}$ from snail $H$. aspersa, which showed higher antiproliferative activity in the MTT assay, were further used in morphological studies that aimed to analyze the mechanisms that mediate their anticancer action and the nature of the cell death induced in HT-29 carcinoma cells. The fluorescent and transmission electron microscopy studies revealed typical apoptotic alterations in the cellular and nuclear morphology of the tumor cells treated with the tested samples. Apoptotic cell death is an important biological mechanism that contributes to the maintenance and integrity of multicellular organisms and an important factor in preventing cancer. Thus, the ability to induce apoptosis in tumor cells is a desired property of the anticancer therapeutics. 
Our results are in line with the previously published data, indicating a significant proapoptotic activity of molluscan hemocyanins in various tumor cell lines [4,33-35] and suggesting their potential use in anticancer therapy.
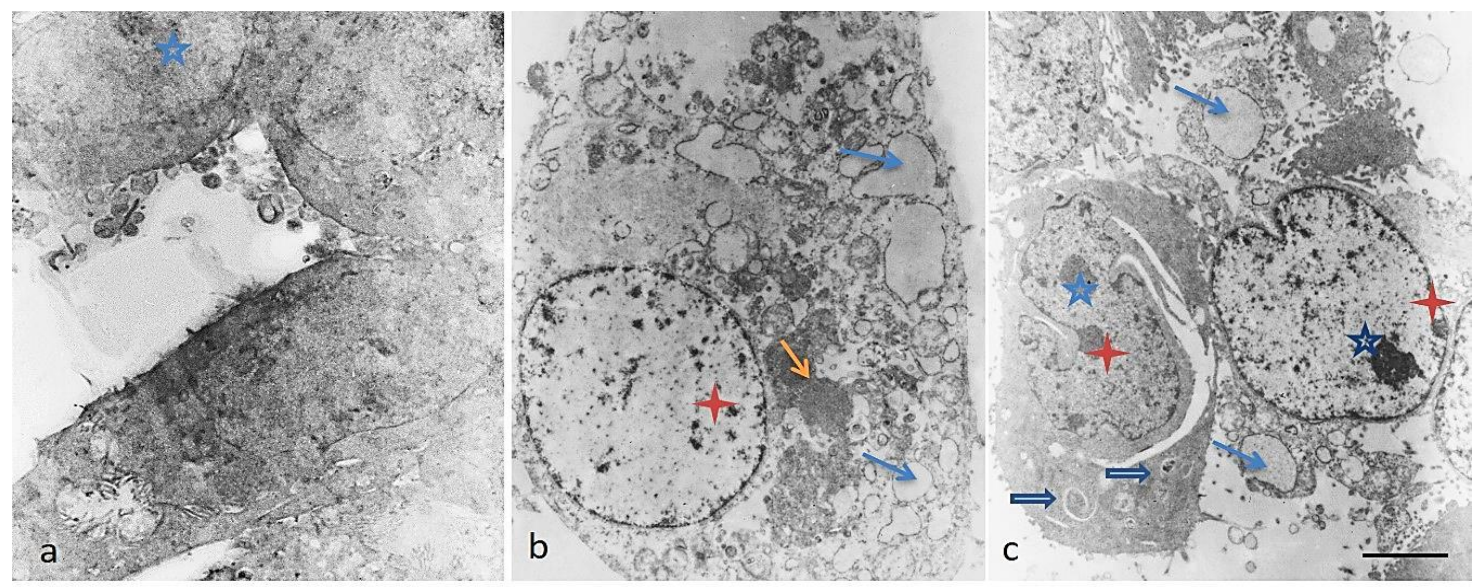

Figure 5. Transmission electron microscopy images of HT-29 cells after treatment with bioactive compounds isolated from Helix aspersa. (a) Control HT-29 cells with normal morphology: blue five-point star-nucleolus. (b) HT-29 cells treated with the subunits $\alpha-\mathrm{HaH}$ with affected cell morphology: red four-point star-granules of highly condensed chromatin, thin blue arrow-numerous vacuoles, thin orange arrow-electron-dense cytoplasmic structures. (c) HT-29 cells treated with the mucus of Helix aspersa with impaired morphology: blue five-point star-nucleolus, red four-point star-granules of highly condensed chromatin, thin blue arrow-numerous vacuoles, blue filled arrow-presence of single autophagosomes or mitophagosome-like structures. TEM scale bar $=2 \mu \mathrm{m}$.

\section{Conclusions}

The tested hemocyanin samples isolated from garden snails H. aspersa and H. lucorum, marine snail $R$. venosa, as well as the mucus from garden snail $H$. aspersa significantly decreased the cell viability of HT-29 carcinoma cells. The mucus and $\alpha-\mathrm{HaH}$ from snail $H$. aspersa were identified as bioactive substances with higher antiproliferative activity against HT-29 carcinoma cells. The mechanism of their antitumor activity includes the induction of apoptosis. In the combination with their already known immunogenic effect, these findings support further studies of molluscan hemocyanins as potential therapeutic agents against colorectal cancer.

Author Contributions: Conceptualization, P.D. and R.T.; methodology, A.D., L.V., A.G., and K.T.; validation, I.I. and I.V.; formal analysis, V.D.; investigation, A.G., K.T., I.I., R.T., and P.D.; resources, S.P., P.D., and R.T.; data curation, R.T.; writing—original draft preparation, A.G.; writing—review and editing, K.T., R.T., and P.D.; visualization, A.G. and K.T.; supervision, S.P., R.T., and P.D.; project administration, P.D. and S.P.; funding acquisition, P.D. and S.P. All authors have read and agreed to the published version of the manuscript.

Funding: Ministry of Education and Science of the Republic of Bulgaria supported by National Program "Innovative Low-Toxic and Biologically Active Means for Precision Medicine" - BioActiveMed, grant number Д01-217/30.11.2018, and Ministry of Education and Science of the Republic of Bulgaria and the Operational Program "Science and Education for Smart Growth" 2014-2020, co-financed by the European Union through the European Structural and Investment Funds, grant number BG05M2OP001-2.009-0019-C01/02.06.2017.

Acknowledgments: We thank Zdravka Stoichkova, Svetlana Vladova, and Boycho Nikolov (IEMPAM-BAS) for technical assistance.

Conflicts of Interest: The authors declare no conflict of interest. The funders had no role in the design of the study; in the collection, analyses, or interpretation of data; in the writing of the manuscript; or in the decision to publish the results. 


\section{Abbreviations}

$\begin{array}{ll}\text { AO } & \text { Acridine orange } \\ \text { ATCC } & 4^{\prime} \text {,6-Diamidine-2'-phenylindole dihydrochloride } \\ \text { DMEM } & \text { Dulbecco's modified Eagle's medium } \\ \text { LD } & \text { Linear dichroism } \\ \text { DMSO } & \text { Dimethyl sulfoxide } \\ \text { EB } & \text { Ethidium bromide } \\ \text { HaH } & \text { Helix aspersa hemocyanin } \\ \text { HIH } & \text { Helix lucorum hemocyanin } \\ \text { KLH } & \text { Keyhole limpet hemocyanin } \\ \text { MTT } & \text { Methyl thiazol tetrazolium bromide } \\ \text { PBS } & \text { Phosphate-buffered saline } \\ \text { RvH } & \text { Rapana venosa hemocyanin } \\ \text { TEM } & \text { Transmission electron microscopy }\end{array}$

\section{References}

1. Falzone, L.; Salomone, S.; Libra, M. Evolution of cancer pharmacological treatments at the turn of the third millennium. Front. Pharmacol. 2018, 9, 1300. [CrossRef] [PubMed]

2. Cragg, G.M.; Pezzuto, J.M. Natural products as a vital source for the discovery of cancer chemotherapeutic and chemopreventive agents. Med. Princ. Pract. 2016, 25, 41-59. [CrossRef] [PubMed]

3. Wang, L.; Dong, C.; Li, X.; Han, W.; Su, X. Anticancer potential of bioactive peptides from animal sources. Oncol. Rep. 2017, 38, 637-651. [CrossRef] [PubMed]

4. Antonova, O.; Toncheva, D.; Rammensee, H.G.; Floetenmeyer, M.; Stevanovic, S.; Dolashka, P. In vitro antiproliferative effect of Helix aspersa hemocyanin on multiple malignant cell lines. Zeitschrift für Naturforschung C 2014, 69, 325-334. [CrossRef]

5. Becker, M.I.; Arancibia, S.; Salazar, F.; Del Campo, M.; De Ioannes, A. Mollusk Hemocyanins as Natural Immunostimulants in Biomedical Applications, in Immune Response Activation. Duc, G.H.T., Ed.; InTech: Croatia, Rijeka, 2014; pp. 45-72.

6. Pizarro-Bauerle, J.; Maldonado, I.; Sosoniuk-Roche, E.; Vallejos, G.; López, M.N.; Salazar-Onfray, F.; Aguilar-Guzmán, L.; Valck, C.; Ferreira, A.; Becker, M.I. Molluskan hemocyanins activate the classical pathway of the human complement system through natural antibodies. Front. Immunol. 2017, 8, 188. [CrossRef]

7. Mora, J.J.; Del Campo, M.; Villar, J.; Paolini, F.; Curzio, G.; Venuti, A.; Jara, L.; Ferreira, J.; Murgas, P.; Lladser, A.; et al. Immunotherapeutic potential of mollusk hemocyanins in combination with human vaccine adjuvants in murine models of oral cancer. J. Immunol. Res. 2019, 2019, 7076942.

8. Kato, S.; Matsui, T.; Gatsogiannis, C.; Tanaka, Y. Molluscan hemocyanin: Structure, evolution, and physiology. Biophysical Rev. 2018, 10, 191-202. [CrossRef]

9. Paccagnella, M.; Bologna, L.; Beccaro, M.; Micetic, I.; Di Muro, P.; Salvato, B. Structural subunit organization of molluscan hemocyanins. Micron 2004, 35, 21-22. [CrossRef]

10. Sandra, K.; Dolashka-Angelova, P.; Devreese, B.; Van Beeumen, J. New insights in Rapana venosa hemocyani $\mathrm{N}$-glycosylation resulting from on-line mass spectrometric analyses. Glycobiology 2007, 17, 141-156. [CrossRef]

11. Arancibia, S.; Salazar, F.; Becker, M.I. Hemocyanins in the immunotherapy of superficial bladder cancer. In Bladder Cancer-From Basic Science to Robotic Surgery; Canda, A.E., Ed.; InTech: Croatia, Rijeka, 2012; pp. 221-242.

12. Dolashka, P.; Velkova, L.; Shishkov, S.; Kostova, K.; Dolashki, A.; Dimitrov, I.; Atanasov, B.; Devreese, B.; Voelter, W.; Van Beeumen, J. Glycan structures and antiviral effect of the structural subunit RvH2 of Rapana hemocyanin. Carbohydr. Res. 2010, 345, 2361-2367. [CrossRef]

13. Zhong, T.-Y.; Arancibia, S.; Born, R.; Tampe, R.; Villar, J.; Del Campo, M.; Manubens, A.; Becker, M.I. Hemocyanins stimulate innate immunity by inducing different temporal patterns of proinflammatory cytokine expression in macrophages. J. Immunol. 2016, 196, 4650-4662. [CrossRef] 
14. Riggs, D.R.; Jackson, B.J.; Vona-Davis, L.; Nigam, A.; McFadden, D.W. In vitro effects of keyhole limpet hemocyanin in breast and pancreatic cancer in regards to cell growth, cytokine production, and apoptosis. Am. J. Surg. 2005, 189, 680-684. [CrossRef] [PubMed]

15. Dolashka, P.; Velkova, L.; Iliev, I.; Beck, A.; Dolashki, A.; Yossifova, L.; Toshkova, R.; Voelter, W.; Zacharieva, S. Antitumor activity of glycosylated molluscan hemocyanins via Guerin ascites tumor. Immunol. Invest. 2011, 40, 130-149. [CrossRef]

16. Salazar, M.L.; Jiménez, J.M.; Villar, J.; Rivera, M.; Báez, M.; Manubens, A.; Becker, M. N-Glycosylation of mollusk hemocyanins contributes to their structural stability and immunomodulatory properties in mammals. J. Biol. Chem. 2019, 294, 19546-19564. [CrossRef] [PubMed]

17. Dolashka-Angelova, P.; Schwarz, H.; Dolashki, A.; Stevanovic, S.; Fecker, M.; Saeed, M.; Voelter, W. Oligomeric stability of Rapana venosa hemocyanin $(\mathrm{RvH})$ and its structural subunits. Biochim. Biophys. Acta. 2003, 1646, 77-85. [CrossRef]

18. Velkova, L.; Dimitrov, I.; Schwarz, H.; Stevanovic, S.; Voelter, W.; Salvato, B.; Dolashka-Angelova, P. Structure of hemocyanin from garden snail Helix lucorum. Comp. Biochem. Physiol. 2010, 157, 16-25. [CrossRef] [PubMed]

19. Dolashki, A.; Nissimova, A.; Daskalova, E.; Velkova, L.; Topalova, Y.; Hristova, P.; Traldi, P.; Voelter, W.; Dolashka, P. Structure and antibacterial activity of isolated peptides from the mucus of garden snail Cornu aspersum. Bulg. Chem. Commun. 2018, 50C, 195-200.

20. Laemmli, U.K. Cleavage of Structural Proteins during the Assembly of the Head of Bacteriophage T4. Nature 1970, 227, 680-685. [CrossRef]

21. Schägger, H.; von Jagow, G. Blue Native Electrophoresis for Isolation of Membrane Protein Complexes in Enzymatically Active Form. Anal. Biochem. 1991, 199, 223-231. [CrossRef]

22. Mossmann, T. Rapid colorimetric assay of cellular growth and survival: Application to proliferation and cytotoxicity assays. J. Immunol. Methods 1983, 65, 55-63. [CrossRef]

23. Wahab, I.; Abdul, A.; Alzubairi, A.; Elhassan, M.; Mohan, S. In vitro ultramorphological assessment of apoptosis induced by zerumbone on (HeLa). J. Biomed. Biotechnol. 2009, 2009, 769568. [PubMed]

24. Gielens, C.; De Sadeleer, J.; Preaux, G.; Lontie, R. Identification, separation and cheracterization of the hemocyanin components of Helix aspersa. Comp. Biochem. Phys. Part B 1987, 88, 181-186. [CrossRef]

25. Luo, W.; Yang, G.; Luo, W.; Cao, Z.; Liu, Y.; Qiu, J.; Chen, G.; You, L.; Zhao, F.; Zheng, L.; et al. Novel therapeutic strategies and perspectives for metastatic pancreatic cancer: Vaccine therapy is more than just a theory. Cancer Cell Int. 2020, 20, 66. [CrossRef] [PubMed]

26. Dolashki, A.; Dolashka, P.; Stenzl, A.; Stevanovic, S.; Aicher, W.K.; Velkova, L.; Velikova, R.; Voelter, W. Antitumour activity of Helix hemocyanin against bladder carcinoma permanent cell lines. Biotech. Biotech. Equip. 2019, 33, 1-13. [CrossRef]

27. Dolashka-Angelova, P.; Stefanova, T.; Livaniou, E.; Velkova, L.; Klimentzou, P.; Stevanovic, S.; Salvato, B.; Neychev, H.; Voelter, W. Immunological potential of Helix vulgaris and Rapana venosa hemocyanins. Immunol. Invest. 2008, 37, 822-840. [CrossRef] [PubMed]

28. Miles, D.; Roché, H.; Martin, M.; Perren, T.J.; Cameron, D.A.; Glaspy, J.; Dodwell, D.; Parker, J.; Mayordomo, J.; Tres, A.; et al. Phase III multicenter clinical trial of the sialyl-TN (STn)-keyhole limpet hemocyanin (KLH) vaccine for metastatic breast cancer. Oncologist 2011, 16, 1092-1100. [CrossRef]

29. Gilewski, T.A.; Ragupathi, G.; Dickler, M.; Powell, S.; Bhuta, S.; Panageas, K.; Koganty, R.R.; Chin-Eng, J.; Hudis, C.; Norton, L.; et al. Immunization of high-risk breast cancer patients with clustered sTn-KLH conjugate plus the immunologic adjuvant QS-21. Clin. Cancer Res. 2007, 13, 2977-2985. [CrossRef]

30. McFadden, D.W.; Riggs, D.R.; Jackson, B.J.; Vona-Davis, L. Keyhole limpet hemocyanin, a novel immune stimulant with promising anticancer activity in Barrett's esophageal adenocarcinoma. Am. J. Surg. 2003, 186, 552-555. [CrossRef]

31. Matusiewicz, M.; Kosieradzka, I.; Niemiec, T.; Grodzik, M.; Antushevich, H.; Strojny, B.; Gołębiewska, M. In Vitro Influence of Extracts from Snail Helix aspersa Müller on the Colon Cancer Cell Line Caco-2. Int. J. Mol. Sci. 2018, 19, 1064. [CrossRef]

32. Gesheva, V.; Chausheva, S.; Mihaylova, N.; Manoylov, I.; Doumanova, L.; Idakieva, K.; Tchorbanov, A. Anti-cancer properties of gastropodan hemocyanins in murine model of colon carcinoma. BMC Immunol. 2014, 15, 34. [CrossRef] 
33. Stenzl, A.; Dolashki, A.; Stevanovic, S.; Voelter, W.; Aicher, W.; Dolashka, P. Cytotoxic effects of Rapana venosa hemocyanin on bladder cancer permanent cell lines. J. US China Med. Sci. 2016, 13, 79-188.

34. Antonova, O.; Yossifova, L.; Staneva, R.; Stevanovic, S.; Dolashka, P.; Toncheva, D. Changes in the gene expression profile of the bladder cancer cell lines after treatment with Helix lucorum and Rapana venosa hemocyanin. J. Buon. 2015, 20, 180-187. [PubMed]

35. Somasundar, P.; Riggs, D.R.; Jackson, B.J.; McFadden, D.W. Inhibition of melanoma growth by hemocyanin occurs via early apoptotic pathways. Am. J. Surg. 2005, 190, 713-716. [CrossRef] [PubMed]

(C) 2020 by the authors. Licensee MDPI, Basel, Switzerland. This article is an open access article distributed under the terms and conditions of the Creative Commons Attribution (CC BY) license (http://creativecommons.org/licenses/by/4.0/). 